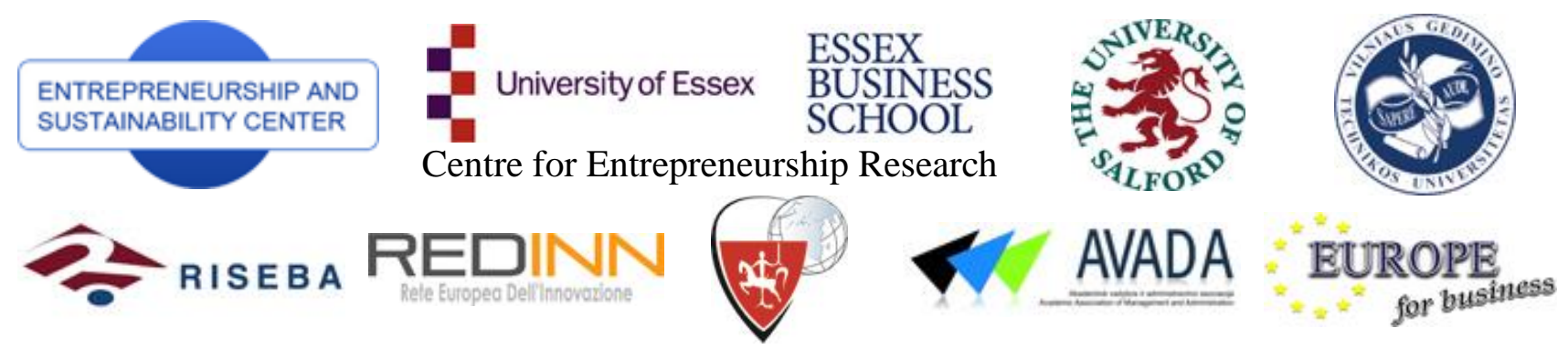

ENTREPRENEURSHIP AND SUSTAINABILITY ISSUES

ISSN 2345-0282 (online) http://jssidoi.org/jesi/aims-and-scope-of-research/

2013 Volume 1(1): 55-66

http://dx.doi.org/10.9770/jesi.2013.1.1(6)

\title{
LITHUANIAN MANUFACTURING TRENDS IN THE CONTEXT OF DEVELOPED AND DEVELOPING COUNTRIES*
}

\author{
Gitana Dudzevičiūtė \\ The General Jonas Žemaitis Military Academy of Lithuania, Šilo Str.5A, LT-10322 Vilnius, Lithuania \\ Vilnius Gediminas Technical University, Sauletekio Av. 11, LT-10223 Vilnius, Lithuania \\ E-mail: gitana.dudzeviciute@vgtu.lt
}

Received 20 March 2013; accepted 15 June 2013

\begin{abstract}
The purpose of this paper is to assess the main aspects of the Lithuanian manufacturing industries in the global context. Two approaches are prevailing in the scientific studies analyzing structural changes of economy. The first seeks to identify statistically certain change in economic structure using three-sector hypothesis. The second approach focuses on in-depth structural analysis of the particular sector over time. This study supports the second approach and examines the structural changes in the manufacturing industry of developed and developing countries and draw the Lithuanian picture on the basis of 2000-2009. To this end, two economics tools, namely, the structural changes indicators and Finger-Kreinin dissimilarity index are applied for this purpose. The main findings related to the manufacturing sector's structural tendencies of the Lithuanian economy in the context of developed and developing countries. First of all, the manufacturing industry is looked from the point of view of three economies, such as developed, developing countries and Lithuania's. The author highlights the main trends of manufacturing industry in global context. After further in-depth analysis of the Lithuanian manufacturing structural changes in the context of developed and developing countries has been carried out and new evidence on manufacturing distribution profiles has been provided, concluding remarks have been made. The insights from this study could be useful guide to the Lithuanian manufacturing industry for the need to promote sustainable development in the global context.
\end{abstract}

Keywords: Structural changes, manufacturing, absolute structural change rate, intensity coefficient, dissimilarity index.

Reference to this paper should be made as follows: Dudzevičiūtè, G. 2013. Lithuanian manufacturing trends in the context of developed and developing countries, Entrepreneurship and Sustainability Issues 1(1): 55-66.

http://dx.doi.org/10.9770/jesi.2013.1.1(6)

JEL classifications: L16, L6, O14.

\section{Introduction}

Theory of structural change have three stages of production, such as primary, secondary and tertiary (Fisher and Clark 1957; Kamaruddin and Masron 2010). Primary production is concerned with the extraction of raw materials through agriculture, fishery and forestry sectors. Low-income countries are dominated by primary sector. Secondary production is concerned through manufacturing and construction. Middle-income countries are often dominated by the secondary sector. Tertiary production is concerned with the provision of

\footnotetext{
* Research prepared within framework of Long-term Economic Research Program, topic "Energetically secure and sustainable restructuring of Lithuanian industry sectors in the context of world economy development tendencies' confirmed by Research Council of Lithuania, IEP-01/2012.
} 
services. High-income countries are dominated by the tertiary sector (Kamaruddin and Masron 2010). Gawlikowska-Hueckel and Uminski (2008) in their investigation argued, that the sectoral approach is useful because it allows us:

- to observe the most general patters of structural changes that are taking place in country and its regions;

- to trace employment trends and workforce transfers between sectors;

- to identify the phase of development in which country find itself and to make intemational comparisons and predictions;

- to formulate industrial policy recommendations and to criticise govemment action in this area;

- to prepare a set of reforms, needed to carry out necessary EU-oriented adjustments in the light of EU industrial policy directives.

Global manufacturing production is shifting gradually from developed countries to developing economies, as companies move to benefit from cheaper labour, lower social costs and large markets in countries like China and India (United Nations Industrial Development Organization 2011). According to the data of United Nations Industrial organization (UNIDO), the share of manufacturing value added in gross domestic product (GDP) declined from $18 \%$ in 1990 to $17 \%$ in 2010 in developed countries and rose from $18 \%$ to $22 \%$ in developing ones. Over a period of 1990-2010, manufacturing value added of global economy grew almost 3 $\%$ annually; developed economies reported $1.7 \%$ annual growth rate in manufacturing and it was less than the growth of GDP, which made $2 \%$. In the same period of time, developing countries recorded the growth of almost $6 \%$ in manufacturing and it was slightly higher rate than the $5 \%$ GDP growth. In 1990, developing countries were producing about $20 \%$ of world GDP and this share had risen to $30 \%$ by 2010 (United Nations Industrial Development Organization 2011). Manufacturing in developing economies is highly concentrated. Five leading economies (China, India, Brazil, Taiwan Province of China and Mexico) recorded $62 \%$ share in developing economy manufacturing value added, up from $53 \%$ in 2000 and $36 \%$ in 1990. China had faster average growth of manufacturing value added than other developing economies over a period of 1990-2010, its share has tripled since 1990 from $13 \%$ to $43 \%$ in manufacturing value added of developing countries (United Nations Industrial Development Organization 2011). During 2000-2008, global manufacturing grew by $3 \%$ annually (in developing countries $7 \%$ ). The financial crisis affected developed economies more than developing. Manufacturing value added in developed countries declined by $8 \%$ from 2008 to 2009, while developing countries slowed growth to $3 \%$ in 2009. According to the data of UNIDO, the global crisis affected developing economies in different way depending on their region specific mix of channels such as foreign direct investments, trade, financial flows and others. Europe was the most affected region with manufacturing falling of $7 \%$ (United Nations Industrial Development Organization 2011). This paper aims to draw a picture of the Lithuanian manufacturing sector in the context of developed and developing countries. The author has used UNIDO data related to the manufacturing sector tendencies in the developed and developing countries and the data of the Lithuanian Statistical department and has applied structural changes assessment methods, such as absolute rate, intensity coefficient and Finger-Kreinin dissimilarity index for this purpose. The author has referred to the approach, prevailing in the scientific studies (Matsuyama 2009; Kamaruddin and Masron 2010; Woodall et al. 2012; Noland et al. 2012; Fafaliou and Polemis 2013) and focusing on in-depth structural analysis of the manufacturing sector over time.

The paper is organized into three sections. Section 1 provides an introduction. A brief review of the empirical studies and methodology particularly on the manufacturing sector trends is made in Section 2. Section 3 looks briefly into some economic indicators assessing manufacturing sector's structural changes of the developed and developing countries, and Lithuania. Section 4 concludes summarizing the main trends observed.

\section{Empirical studies' and methodology review}

The overview of the recent scientific works shows that two approaches are prevailing in the researches analyzing economic structure. The first seeks to identify statistically certain change in economic structure using three sector (agricultural, industry and services) hypothesis (Teigeiro and Solis 2007; Albu 2010; Gil' Mundinov 2011; Jiang 2011; Mao and Yao 2012; Dudzevičiūtè 2012, 2013). The second approach focuses on in-depth structural analysis of the particular sector over time (Tanuwidjaja and Thangavelu 2007; Matsuyama 2009; Thomas et al. 2009; Kamaruddin and Masron 2010; Rosenzweig and Easton 2010; Rezitis and Kalantzi 2011; Woodall et al. 2012; Mermod and Dudzevičiūtè 2011; Steinbuks 2012; Noland et al. 2012; Smaliukienè et al. 2012; Fafaliou and Polemis 2013). Manufacturing sector has been analyzed from different angles and different results were gotten through regions and countries. Salim (2008) empirically estimated the firm-specific productive capacity realization factors using the stochastic frontier production 
function and analyses explaining realization rates across firms and over time. Using the Firm level panel data from Bangladesh food manufacturing, the study showed that capacity realization rates widely vary across firms and over time. The author determined the average rate of realization with $65 \%$ implying that most of the firms are producing away from their full production capacity. The results also showed that firm size and outward orientation had positive impact on realization, while market structure, capital intensity and effective rate of assistance had negative effect. The author suggested further reform of the domestic and trade policies to ensure competition and competitiveness of the manufacturing sector and of the country. Kim and Shafi' $i$ (2009), investigating Malaysian manufacturing industries over a period of 2000-2004, decomposed productivity growth into technical progress, technical efficiency change, allocative efficiency and scale efficiency change. Research results show that total productivity was driven mainly by technical progress; however, it was hurt by deteriorating technical efficiency. Authors revealed that scale efficiency and allocative efficiency were also significant factors impacting on total productivity. The skill and quality of workers were identified as the most important determinants of technical efficiency, whereas employee quality, foreign ownership and imports sustained technical progress.

Kim et al. (2009) analyzed the contributions of patents to total factor productivity in Korean manufacturing industries over a period 1981-1999. The investigation showed that both domestic and foreign-resident patent applications had positive effects on productivity and that foreign-resident patent applications had a larger effect than domestic patents in improving total factor productivity in the Korean manufacturing sector. Kamaruddin and Masron (2010) examined the structural changes and the sources of growth in the manufacturing sector in Malaysia. As the results showed, most of the industries were non-resource based such as textiles, electrical and electronic products. The research revealed that export is increasingly an important factor of change in the industrial growth patterns for the Malaysian economy. The authors have concluded that the structural changes in Malaysian economy mainly caused by the reorientation of industrialization strategies as well as by variations in the composition of domestic demand.

Byun et al. (2012) also compared and analyzed the total factor productivity of the manufacturing industries in the metropolitan areas of South Korea, China, and Japan. The manufacturing industries were classified into 10 sectors, and two different time periods (before and after 1997, when the foreign currency crisis began in Korea) were examined. Although the output and total factor productivity in Korea had been increasing since the 1997, the rates of increase in the output and total factor productivity remained behind China. The lower total factor productivity of the companies in Korea compared with those in Japan indicated differences in techniques between these two countries. The researches concluded that the results of the development and competitiveness of the manufacturing industries in Korea, China, and Japan could be useful in establishing promotional strategies and contributing to the economic cooperation among these countries by evaluating their relative competitiveness. Fafaliou and Polemis (2013) in their research assessed the main aspects involved in the competitiveness of manufacturing industries in the Euro zone area (EZ-12), covering the period from 1970 to 2007. The authors concluded that in the long run, a change in labor and capital compensation was not fully passed on to manufacturing growth, while an increase in the market power of the manufacturing sector negatively affected its competitiveness. Steinbuks (2012) investigated interfuel substitution, separately accounting for different types of energy use in the U.K. manufacturing sector. The results indicated that the estimated ownprice elasticities for all fuels and the cross-price elasticities for fossil fuels are significantly higher for thermal heating processes. An increase in real fuel prices in 2001 resulted in higher substitution elasticities based on aggregate data, and lower substitution elasticities for the thermal heating process. The research revealed that technological change was the major determinant of the differences in elasticities before and after the energy price increase.

The overview of the the recent scientific works (Gawlikowska-Hueckel and Uminski 2008; Salim 2008; McCann 2008; Matsuyama 2009; Kumar and Nottestadb 2009; Kim and Shafi'i 2009; Park et al. 2010; Fedderke and Naumann 2011; Boussemart et al. 2011; Sethi et al. 2011; Rezitis and Kalantzi 2011; Saunders 2012; Hasanbeigi et al. 2012; Fafaliou and Polemis 2013) showed that manufacturing sector's trends and development can be analysed on the basis of a wide range of indicators, such as incomeelasticity, productivity growth, employment concentration, share of output in GDP, contribution to total value added,

total spending and different methods can be applied, as follows: an empirical analysis; a case study; comparison analysis; decomposition analysis; panel data analysis; multi-level analysis; stochastic frontier analysis; a life cycle analysis; correlation analysis; regression analysis. To sum up, it can be say, that several statistical methods can be used for this purpose, ranging from simple descriptive indicators to geometric models and econometric techniques. 
In this paper, to better assess the structural changes in manufacturing sector and to study its impact on manufacturing growth, it is useful to measure its structural changes and intensity. The absolute structural changes rate (Memedovic and Iapadre 2010; Dudzevičiūtė 2013), intensity coefficient (Domingo and Tonella 2000; Cortuk and Singh 2010) and Finger-Kreinin dissimilarity index (D index) (Finger and Kreinin 1979; Memedovic and Iapadre 2010) has been used for this purpose.

The absolute structural changes rate shows manufacturing sector's structural change and its impact on manufacturing development. Positive rate value means that structural change accelerates growth; and negative rate reducible development. The absolute structural changes rate is calculated as follows:

$$
\begin{aligned}
& M=D_{i}-D_{0} \\
& M_{\text {sum }}=\sum_{i=1}^{n} M_{i}
\end{aligned}
$$

where: $M$ - the absolute structural change rate; $D_{i}$-economic activity share, $\% ; D_{0}$-economic activity share, $\%$ in the basic year; $M_{\text {sum }}$ - sum of the absolute structural change rate.

The intensity coefficient of structural changes shows the intensity of manufacturing in time $\mathrm{t}_{\mathrm{i}}$, compare with basic period. As the coefficient value greater, as more intensive structural changes going, and conversely. Its formula is as follows:

$$
K=\frac{\left.\sqrt{\sum_{t=2}^{n}\left(S_{t i}\right.}-S_{t 0}\right)^{2}}{m}
$$

where: $K$ - the intensity rate of structural ckanges; $S_{t i}$ - economic activity share; $t i$, to-current and basic time; $n$ - economic activity quantity; $m$ - year.

Finger-Kreinin dissimilarity index (D index) measures how much a given distribution differs from a chosen benchmark. It is calculated as follows:

$$
D=\frac{1}{2} \sum_{i=1}^{n}\left|a_{i}-b_{i}\right|
$$

where: $a_{i}$ and $b_{i}$ show the share of sector $i$ in each of the two distributions.

When a given distribution at a given time is compared to the same distribution in a previous period, the $\mathrm{D}$ index can be used as a measure of structural change (Memedovic and Iapadre 2010).

$\mathrm{D}$ index ranges between zero, denoting equality and one, showing maximum dissimilarity.

The main advantages of these indicators could be named as follows: they are easy to calculate, they are informative for interpretation of their impact on economic development. However, they give only general information and do not reveal the reasons for structural changes.

\section{The overview of manufacturing sector development}

\subsection{Decomposition analysis of manufacturing sector}

This section aims to overview the manufacturing sector structure of the developed and developing countries and to draw the Lithuanian picture on the basis of comparative analysis covering the date of 2000-2009.

Over a period of 1990-2010, manufacturing value added increased by $40 \%$ in developed countries and has nearly tripled in developing countries since 1990. At the same period of time, the developed countries lost their manufacturing value added share in global economy from $79 \%$ in 1990 to $64 \%$ in 2010, whereas the share of developing countries rose from $21 \%$ to $36 \%$ (Fig.1). Average annual growth rate of manufacturing value added in developing countries was considerably higher than in developed economies. Despite the crisis, manufacturing value added grew an average $6 \%$ a year over 2001-2005, and $7 \%$ in 2006-2010, whereas in developed countries the average growth slowed from $1.4 \%$ to $0.2 \%$ respectively. According to the classification of developing countries by income, four groups of economies were distinguished: high income, upper-middle income, lower- middle income and low income (Fig.2, Appendix). 


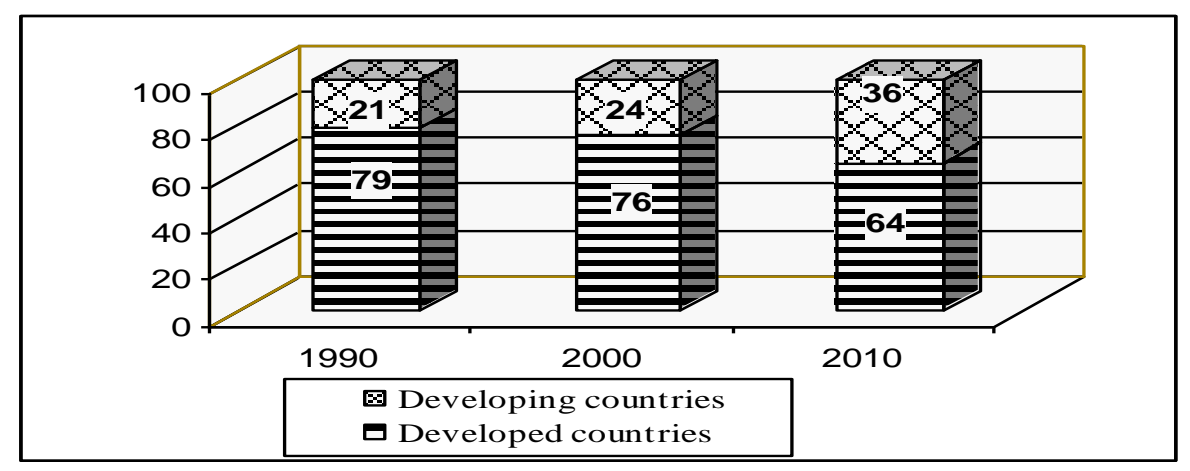

Fig.1. Share of manufacturing value added in global economy, percent Source: UNIDO (2011) data

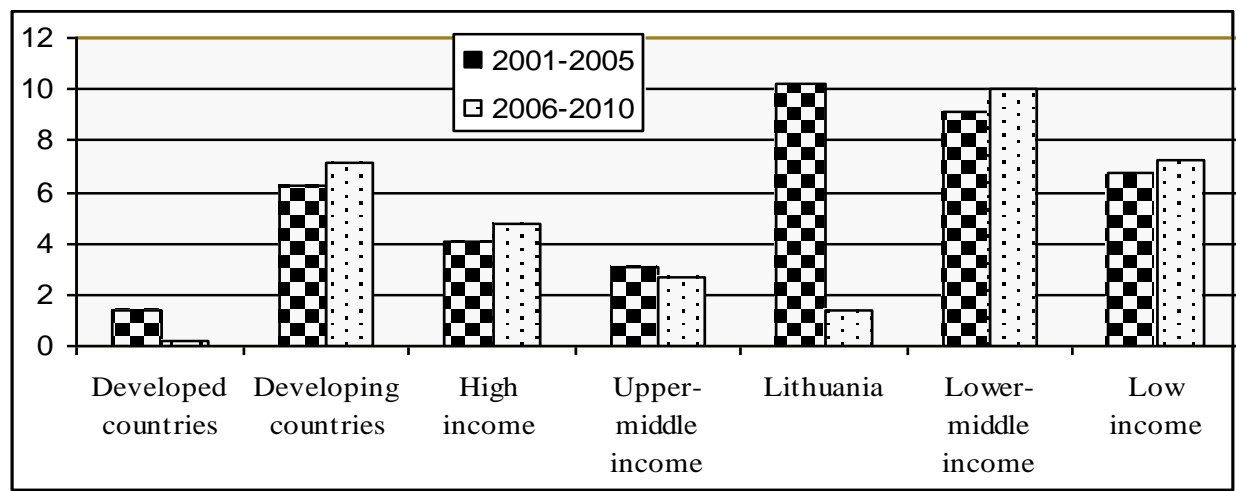

Fig. 2. Average annual growth, percent

Source: UNIDO (2011) data, author's calculations based on the Lithuanian Statistics department (2013) data

Lithuania as the other two Baltic countries- Latvia and Estonia- belongs to upper- middle income economies. There are variations in manufacturing performance among developing economies. Lower- middle income group demonstrated significant average growth with nearly $10 \%$ annually during a period of 2001-2010. China and India had considerable impact on this growth. Over a period of 2001-2005, the Lithuanian manufacturing had the highest growth with $10 \%$ a year among all observed countries' groups.

Due to the global economical and financial crises, the Lithuanian manufacturing value added dropped $15 \%$ in 2008-2009; and this impact on average annual growth rate with $1.4 \%$ over 2006-2010. In developed countries, the leading manufacturing industries in 2000-2009 were machinery and equipment with share of $34 \%$ in 2000 and $45.6 \%$ in 2009, transport equipment (9.9\% and $9.1 \%$ ), chemical and chemical products $(9.3 \%$ and $8.8 \%)$; food, beverages and tobacco (9.5\% and $8.5 \%)$ (Table1).

These sub-sectors made nearly $63 \%$ of manufacturing value added in 2000 and $72 \%$ in 2009 . In the same period of time, the dominant manufacturing sub-sectors in developing economies were machinery and equipment (18.9\% in 2000 and $24.5 \%$ in 2009), chemical and chemical products (10.9\% and $11.0 \%$ ); food, beverages and tobacco (17.2\% and 14.6\%); basic metals (7.1\% and 10.1\%); (textiles and leather (9.9\% and $8.4 \%$ ). They had $64 \%$ contribution to total manufacturing value added in 2000 and $67 \%$ in 2009 . Machinery and equipment growth in developed and developing economies was a result of increase in demand for electronic goods, such as computers, mobile phones and other electronic devices. Developing countries are distinguished from developed of substantial share of textiles and leather products.

In 2000-2009, the dominant manufacturing sub- sectors in Lithuania were coke and refined petroleum with share of $30.2 \%$ in 2000 and $33.9 \%$ in 2009 , food, beverages and tobacco (25.8\% and $22.9 \%$ ), chemical and chemical products $(9 \%$ and $11.1 \%)$. The share of these sub-sectors made $65 \%$ of total manufacturing value added in 2000 and $68 \%$ in 2009. 
Table 1. Manufacturing sub-sectors contribution to total value added, percent

\begin{tabular}{|l|r|r|r|r|r|r|}
\hline \multirow{2}{*}{ Manufacturing sub-sectors } & \multicolumn{2}{|c|}{ Developed countries } & \multicolumn{2}{c|}{ Developing countries } & \multicolumn{2}{|c|}{ Lithuania } \\
\cline { 2 - 6 } & $\mathbf{2 0 0 0}$ & $\mathbf{2 0 0 9}$ & $\mathbf{2 0 0 0}$ & $\mathbf{2 0 0 9}$ & $\mathbf{2 0 0 0}$ & $\mathbf{2 0 0 9}$ \\
\hline Food, beverages and tobacco & 9,5 & 8,5 & 17,2 & 14,6 & 25,8 & 22,9 \\
Textiles and leather & 3,8 & 1,8 & 9,9 & 8,4 & 11,3 & 4,4 \\
Wood and wood products & 2,1 & 1,4 & 1,6 & 1,1 & 4,1 & 4,4 \\
Paper and print & 8,3 & 6,3 & 4,6 & 3,5 & 2,2 & 2,1 \\
Chemical and chemical products & 9,3 & 8,8 & 10,9 & 11,0 & 9,0 & 11,1 \\
Coke, refined petroleum & 2,6 & 2,2 & 7,0 & 5,0 & 30,2 & 33,9 \\
Rubber and plastics & 3,0 & 2,4 & 3,6 & 3,5 & 1,8 & 3,2 \\
Non-metallic minerals & 3,3 & 2,5 & 5,4 & 4,9 & 2,5 & 2,0 \\
Basic metals & 4,5 & 3,6 & 7,1 & 10,1 & 0,7 & 0,5 \\
Fabricated metal products & 6,2 & 5,0 & 4,3 & 3,5 & 1,5 & 2,2 \\
Machinery and equipment & 34,0 & 45,6 & 18,9 & 24,5 & 6,3 & 6,2 \\
(instruments) & 9,9 & 9,1 & 7,2 & 7,5 & 2,1 & 1,4 \\
Transport equipment & 3,5 & 2,8 & 2,3 & 2,4 & 2,5 & 5,7 \\
Furniture and other & $\mathbf{1 0 0}$ & $\mathbf{1 0 0}$ & $\mathbf{1 0 0}$ & $\mathbf{1 0 0}$ & $\mathbf{1 0 0}$ & $\mathbf{1 0 0}$ \\
\hline Total manufacturing & & & & &
\end{tabular}

Source: UNIDO (2011), author's calculations based on the Lithuanian Statistics department (2013) data

Textile and leather products were one of the leading sub-sectors in 2000 with contribution of $11.3 \%$ to total manufacturing value added, however, in 2009 its share decreased by 4.4\%. Figure 3 and Figure 4 show leading manufacturing sub-sectors comparison by countries in 2000 and 2009.

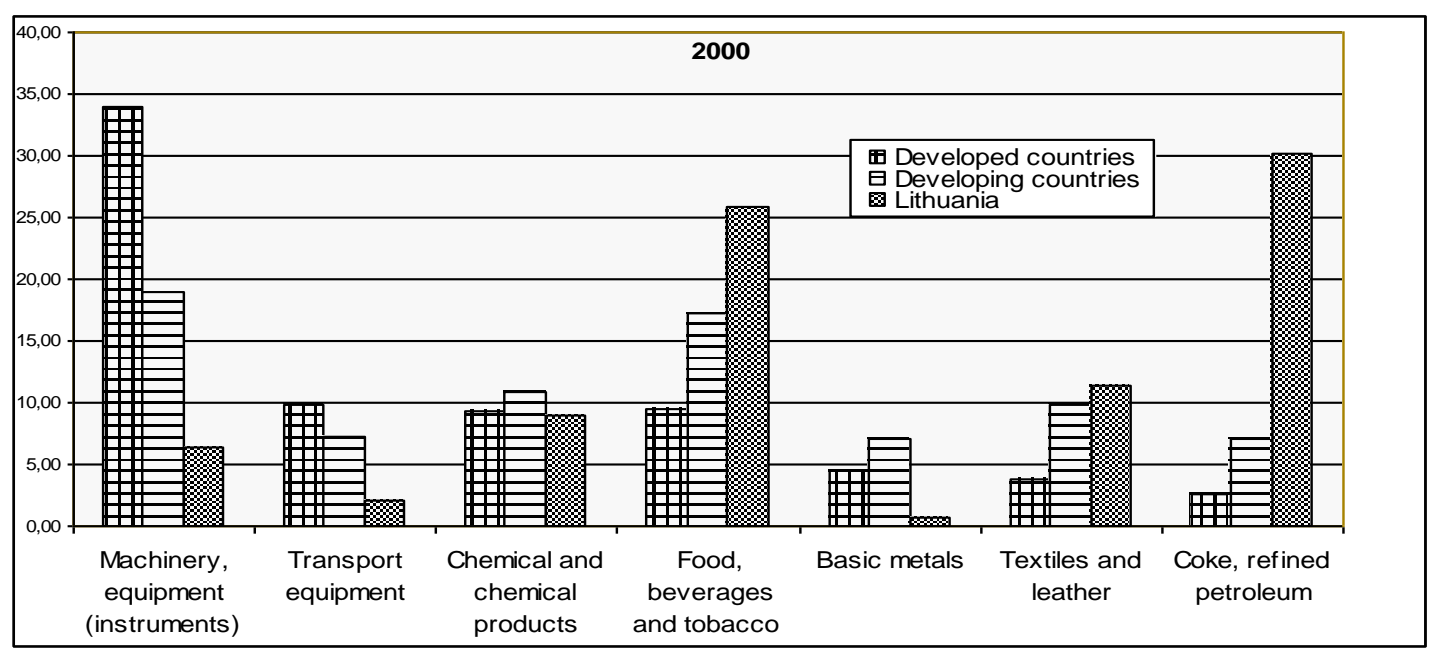

Fig.3. Leading manufacturing sub-sectors in 2000, percent Source: UNIDO (2011), Lithuanian Statistics department (2013)

In 2000, the Lithuanian manufacturing distinguished from developed and developing countries by substantial dominance of coke and refined petroleum, food and beverages industries. Machinery and equipment industry prevailed in developed economies. Food and beverages, machinery and equipment were leading sub-sectors in developing countries. Over a period of 2000-2009, the leading sectors remained the same in the countries observed, despite the changes of their contribution to total manufacturing value added (Figure 4). The coke and refined petroleum remained the leading sector in Lithuania; and it increased the contribution to total manufacturing value added by 3.7 percentage points. In the same period of time, the Lithuanian food and beverages industry's share decreased by 2.9 percentage points. In 2000-2009, machinery and equipment shares rose in developed countries as well as developing by 11.6 percentage points and 5.6 percentage points respectively. 


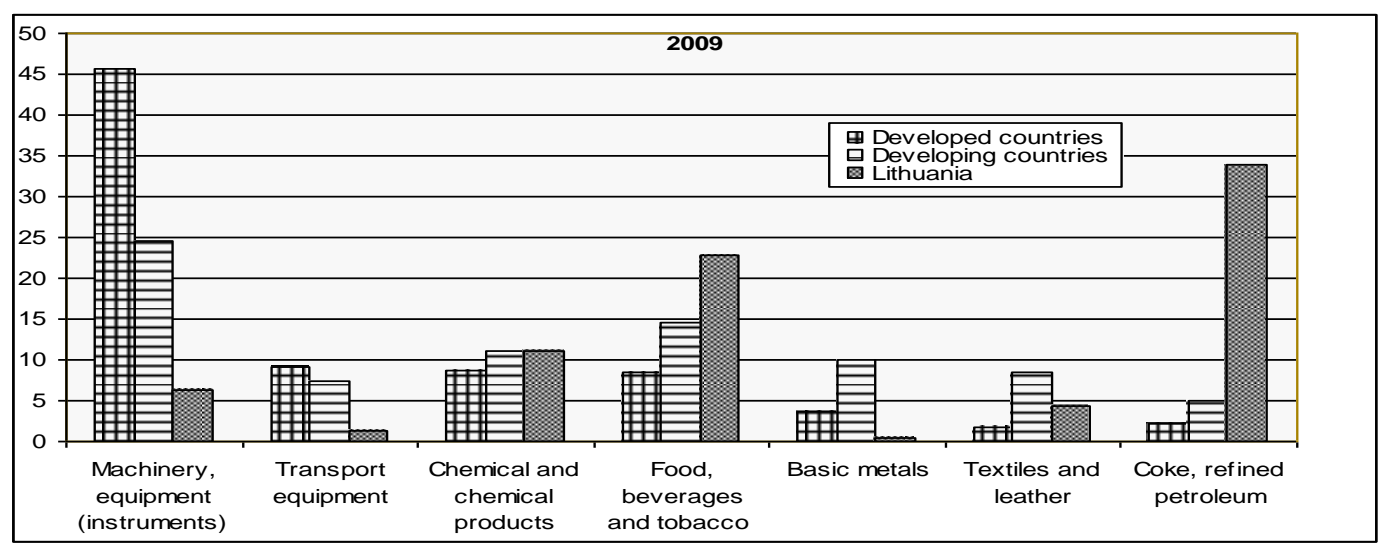

Fig.4. Leading manufacturing sub-sectors in 2009, percent Source: UNIDO (2011), author's calculations based on Lithuanian Statistics department (2013) data

The contribution of food and beverages industry's to manufacturing value added decreased by 2.6 percentage points. Structural changes in manufacturing have been summarized in Table 2 by using absolute structural changes rate.

Table 2. Absolute structural changes rate in manufacturing industry over 2000-2009, percentage points

\begin{tabular}{|l|c|c|c|}
\hline \multicolumn{1}{|c|}{ Sub-sectors } & $\begin{array}{c}\text { Developed } \\
\text { countries }\end{array}$ & $\begin{array}{c}\text { Developing } \\
\text { countries }\end{array}$ & Lithuania \\
\hline Machinery, equipment & 11,6 & 5,6 & $-0,1$ \\
Transport equipment & $-0,8$ & 0,3 & $-0,7$ \\
Chemical and chemical & $-0,5$ & 0,1 & 2,1 \\
products & $-1,0$ & $-2,6$ & $-2,9$ \\
Food, beverages and tobacco & $-0,9$ & 3,0 & $-0,2$ \\
Basic metals & $-2,0$ & $-1,5$ & $-6,9$ \\
Textiles and leather & $-0,4$ & $-2,0$ & 3,7 \\
Coke, refined petroleum & $-6,0$ & $-2,9$ & 5,0 \\
Other & $\mathbf{0 , 0}$ & $\mathbf{0 , 0}$ & $\mathbf{0 , 0}$ \\
Total &
\end{tabular}

Source: author's calculations based on UNIDO (2011) and Lithuanian Statistics department (2013) data

Based on the estimated results of structural changes in manufacturing sector over 2000-2009, it can be concluded, that the manufacturing sector development was negatively impacted by textiles and leather, food, beverages and tobacco in all countries. Absolute structural change rate shows, that machinery and equipment growth positively impacted on manufacturing sector development in developed countries as well as developing ones. Refined petroleum and chemical sub-sectors stimulated and sustained manufacturing development in Lithuania.

Next section has evaluated the structural change process in manufacturing sector and its intensity by countries.

\subsection{The assessment of the manufacturing sector's structural changes}

To better assess the structural changes and to study its impact on economic growth, it is useful to measure its intensity. The intensity coefficient and Finger-Kreinin dissimilarity index has been used for this purpose. The results obtained by applying the intensity coefficient and D index to the distribution of manufacturing value-added have been summarized in Table 3, Figure 5 and Figure 6. Having evaluated structural manufacturing changes in 2000-2009, using intensity coefficient, it can be stated, that the Lithuanian structural changes intensity was very close to the developed countries intensity. 
Table 3. The intensity coefficient of the structural changes in 2000-2009

\begin{tabular}{|l|c|c|c|}
\hline \multicolumn{1}{|c|}{ Sub-sectors } & $\begin{array}{c}\text { Developed } \\
\text { countries }\end{array}$ & $\begin{array}{c}\text { Developing } \\
\text { countries }\end{array}$ & Lithuania \\
\hline Machinery, equipment & 1,2 & 0,6 & 0,0 \\
Transport equipment & 0,1 & 0,0 & 0,1 \\
Chemical and chemical & 0,1 & 0,0 & 0,2 \\
products & 0,1 & 0,3 & 0,3 \\
Food, beverages and tobacco & 0,1 & 0,3 & 0,0 \\
Basic metals & 0,2 & 0,2 & 0,7 \\
Textiles and leather & 0,0 & 0,2 & 0,4 \\
Coke, refined petroleum & 0,6 & 0,3 & 0,5 \\
Other & $\mathbf{2 , 3}$ & $\mathbf{1 , 8}$ & $\mathbf{2 , 2}$ \\
Total & \multicolumn{2}{|c|}{} \\
\hline
\end{tabular}

Source: author's calculations based on UNIDO (2011) and Lithuanian Statistics department (2013) data

Over 2000-2009, the Lithuanian manufacturing intensity coefficient made 2.2 and it was mostly impacted by the structural changes of textile and leather and coke, refined petroleum sub-sectors. Machinery and equipment affected the intensity of manufacturing structural changes in developed as well as developing countries. The intensity coefficient of these countries made 2.3 and 1.8 respectively. Hereafter, FingerKreinin dissimilarity index ( $\mathrm{D}$ index) has been applied in order to compare manufacturing distribution in 2000 and 2009 of the same country (Fig. 5) and different countries (Figure 6). When a given distribution at a certain time is compared to the same distribution in a previous time, the $\mathrm{D}$ index can be used as a measure of structural change.

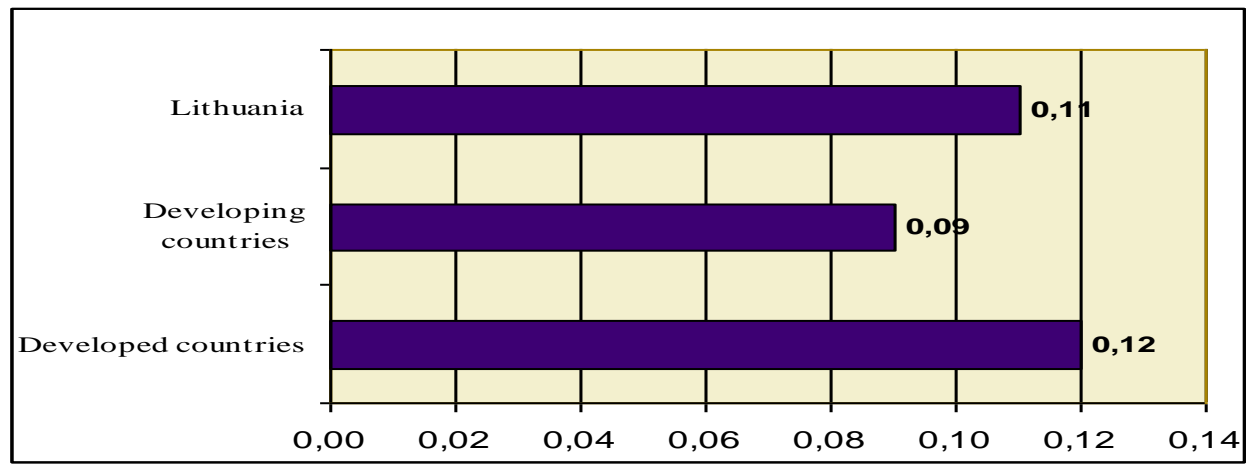

Fig.5. Finger-Kreinin dissimilarity index by countries in 2000-2009

Source: author's calculations based on UNIDO (2011) and Lithuanian Statistics department (2013) data

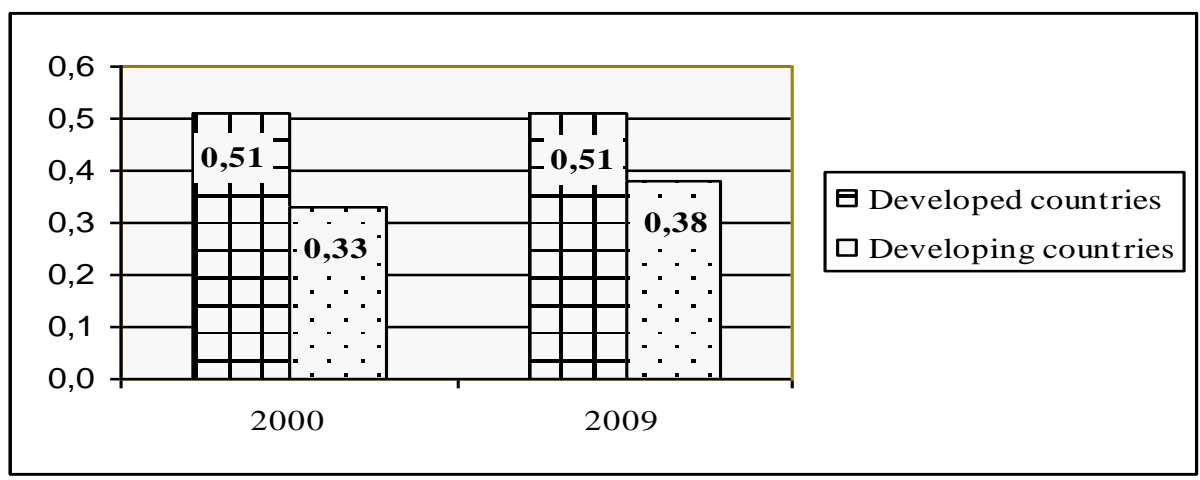

Fig.6. Finger-Kreinin dissimilarity index of Lithuania with developed and developing countries Source: author's calculations based on UNIDO (2011) and Lithuanian Statistics department (2013) data

Figure 5 shows the results obtained by applying the D index to the distribution of manufacturing value-added in selected countries for 2000-2009 period. As dissimilarity index shows, manufacturing 
sector distribution was completely similar in developed and developing countries and Lithuania as well in 2000 compared to 2009. It could be characterized by a higher rate of stability. The economies do not tend to show higher indices of structural change, often denoting the volatility of their specialization patterns. The specialization patterns of economies have been already formed. Figure 6 summarizes the dissimilarity index of Lithuania with developed and developing countries. Several observations have been noted from the results. First, developed countries have higher dissimilarity in their manufacturing distribution profiles with Lithuania's; and the degree of dissimilarity has been relatively stable throughout the studied period. Second, manufacturing distribution of developing countries have had lower dissimilarity index with Lithuania than developed ones and the degree of dissimilarity has risen from 0.33 in 2000 to 0.38 in 2009.

\section{Conclusions}

The overview of statistical data has revealed that global manufacturing production is shifting gradually from developed economies to developing countries. Over a period of 1990-2010, manufacturing value added increased by $40 \%$ in developed countries and has tripled in developing economies since 1990.

There are variations in manufacturing performance among developing economies. Lower- middle income group demonstrated significant average growth with nearly $10 \%$ annually during a period of 2001-2010. Over a period of 2001-2005, the Lithuanian manufacturing had the highest growth with $10 \%$ a year among all observed countries' groups. Due to the global economical and financial crises, the Lithuanian manufacturing value added dropped $15 \%$ in 2008-2009; and this impact on average annual growth rate with $1.4 \%$ over $2006-2010$.

Over 2000-2009, in developed countries, the leading manufacturing industries were machinery and equipment, transport equipment, chemical and chemical products, food, beverages and tobacco. These industries made nearly $63 \%$ of manufacturing value added in 2000 and $72 \%$ in 2009 . In the same period of time, the dominant manufacturing industries in developing economies were machinery and equipment, chemical and chemical products, food, beverages and tobacco; basic metals, textiles and leather. They had $64 \%$ contribution to total manufacturing value added in 2000 and $67 \%$ in 2009 . The dominant manufacturing industries in Lithuania were refined petroleum, food, beverages and tobacco, and chemical products. The share of these sub-sectors made 65\% of total manufacturing value added in 2000 and $68 \%$ in 2009.

Based on the estimated results over 2000-2009 using absolute change rate, it can be concluded, that the manufacturing sector development was negatively impacted by textiles and leather, food, beverages and tobacco sub-sectors in all observed countries. Absolute structural change rate showed that machinery and equipment growth positively impacted on manufacturing sector development in developed countries as well as developing ones. Refined petroleum and chemical sub-sectors sustained manufacturing development in Lithuania.

Intensity coefficient of manufacturing structural changes revealed that the Lithuanian manufacturing structural changes intensity was very similar to the developed countries intensity with 2.2 rate. In developing countries the intensity of structural changes was slower than in advanced economies and in Lithuania. It has shown that the Lithuanian manufacturing distribution was more volatile comparing with developing economies.

Lithuania has had higher dissimilarity in manufacturing distribution profile with developed countries than developing ones. The degree of dissimilarity with developed countries has remained relatively stable throughout the studied period. It has shown that the Lithuanian manufacturing distribution profile has been more similar to developing economies. Dissimilarity degree between the Lithuanian manufacturing distribution and developing economies has increased from 0.33 to 0.38 over a period of 2000-2009.

Evidences provided in this paper lead to general conclusion, that the manufacturing structural shifts are typical to all economies to a certain degree and the implementation of the appropriate economic policy could promote sustainable development of the Lithuanian manufacturing in the global context. 


\section{References}

Albu, Lucian-Liviu. 2010. Trends in structural changes and convergence in EU and in Adriatic-Balkans region, Studies in Business and Economics 5(3):7-66.

Boussemart, J-Ph.; Briec, W.; Taverac, C. 2011. More evidence on technological catching-up in the manufacturing sector, Applied Economics 43: 2321-2330.

Byun, T.; Kim, K.; Choi, H. 2012. Comparative Analysis of the total factor productivity of manufacturing in Northeast Asian metropolitan areas, Growth and Change 43(1): 167-177.

Cortuk, O.; Singh, N. 2010. Structural changes and growth in India, Economics Letters 2: 178-181.

Domingo, C.; Tonella, G. 2000. Towards a theory of structural change, Structural Change and Economic Dynamics 11(1): $209-225$.

Dudzevičiūte, G. 2012. Lithuanian security of energy supply and consumption in the context of the European Union countries. International Scientific Conference "Whither Our Economies" October 15-16, Proceedings: 32-38. ISSN (online) 2029-8501.

Dudzevičiūtè, G. 2013. The research of the economic structural changes: energy consumption aspect, Journal of Security and Sustainability Issues 2(4): 13-23. http://dx.doi.org/10.9770/jssi.2013.2.4(2)

Fafaliou, I.; Polemis, M.L. 2013. Competitiveness of the Euro Zone Manufacturing: a panel data analysis, International Advances in Economic Research 19:45-61.

Fedderke, J.; Naumann, D. 2011. An analysis of industry concentration in South African manufacturing, 1972-2001, Applied Economics 43: 2919-2939.

Finger, J. M.; Kreinin, M.E. 1979. A measure of export similarity and its possible uses, Economic Journal 89(356): 905-912.

Fisher, A. G. B.; Clark, C. 1957. Production, primary, secondary and tertiary, Economic Record 15(28): 24-38.

Gawlikowska-Hueckel, K; Uminski, S. 2008. Structural changes in the economy of Polish regions, European Integration Studies (2): 88-97.

Gil' Mundinov, V. M. 2011. Analysis of structural changes in the Russian economy in conditions of intersectoral competition, Problems of Economic Transition 54 (3): 44-53.

Hasanbeigi, A.; Hasanabadi, A.; Abdorrazaghi, M. 2012. Comparison analysis of energy intensity for five major sub-sectors of the textile industry in Iran, Journal of Cleaner Production 23: 186-194.

Jiang, Y. 2011. Structural change and growth in China under economic reforms: patterns, causes and implications, Review of Urban and Regional Development Studies 23(1): 48-65.

Kamaruddin, R.; Masron, T.A. 2010. Sources of growth in the manufacturing sector in Malaysia: evidence from ARDL and structural decomposition analysis, Asian Academy of Management Journal 15(1): 99-116.

Kim, S.; Shafi'i, M. 2009. Factor determinants of total factor productivity growth in Malaysian manufacturing industries: a decomposition analysis, Asian Pacific Economic Literature: 48-65.

Kim, T.; Maskus, K. E.; Oh, K-Y. 2009. Effects of patents on productivity growth in Korean manufacturing: a panel data analysis, Pacific Economic Review 14(2): 137-154.

Kumar, S.; Nottestadb, D. A. 2009. Flexible capacity design for the focus factory - a case study, International Journal of Production Research 47(5): 1269-1286.

Lithuanian Statistics Department. 2013. Ratios database. Available on the Internet: $<$ http://db1.stat.gov.lt/statbank/default.asp?w=1024>.

Mao, R.; Yao, Y. 2012. Structural change in small open economy: an application to South Korea, Pacific Economic Review 17(1): $29-56$.

Matsuyama, K. 2009. Structural change in an interdependent world: a global view of manufacturing decline, Journal of the European Economic Association 7(2/3): 478-486.

McCann, J. 2008. Leadership in the apparel manufacturing environment: an analysis based on the multi-factor leadership questionnaire, Advanced Management Journal: 73(4): 20-31.

Memedovic, O; Iapadre, L. 2010. Structural change in the world economy: main features and trends. UNIDO, Working Paper (24), $62 \mathrm{p}$. 
Mermod, A.Y.; Dudzevičiūtè, G. 2011. Frequency domain analysis of consumer confidence, industrial production and retail sales for selected European countries, Journal of Business Economics and Management 12(4): 589-602

Noland, M.; Park, D.; Estrada, G.B. 2012. Developing the services sector as engine of growth for Asia: an overview. Peterson Institute for International Economics Working paper. Available on the Internet: 〈http://www.iie.com/publications/wp/wp12-18.pdf> .

Park, R.; Appelbaum, E.; Kruse, D. 2010. Employee involvement and group incentives in manufacturing companies: a multi-level analysis, Human Resource Management Journal 20(3): 227-243.

Rezitis, A.N.; Kalantzi, M.A. 2011. Investigating market structure of the Greek manufacturing industry: a Hall-Roeger approach, Atlantic Economic Journal 39: 383-400.

Rosenzweig, E.D.; Easton, G.S. 2010. Tradeoffs in manufacturing? A meta-analysis and critique of the literature, Production and Operations Management 19(2): 127-141.

Salim, R. A. 2008. Differentials at firm level productive capacity realization in Bangladesh food manufacturing: an empirical analysis, Applied Economics (40): 3111-3126.

Saunders, L. 2012. Employment and earnings: a case study. Review of Black Political Economy 39: 107-119. doi: 10.1007/s12114011-9128-9.

Sethi, S.P.; Veral, E.A.; Shapiro, H.J.; Emelianova, O. 2011. Global manufacturing principles (GMP) - a life-cycle analysis of a company-based code of conduct in the toy industry, Journal of Business Ethics 99: 483-517. doi: 10.1007/s10551-010-0673-0.

Smaliukienè, R.; Dudzevičiūtè, G.; Adekola, A.F.; Aktan, B. 2012. The investigation of Lithuanian growth and industry export dependence on energetic resources, Journal of Security and Sustainability Issues 2(2): 69-78.

Steinbuks, J. 2012. Interfuel substitution and energy use in the U.K. manufacturing sector, The Energy Journal 33(1): 1-29.

Tanuwidjaja, E.; Thangavelu, S. 2007. Structural change and productivity growth in the Japanese manufacturing industry, Global Economic Review 36(4): 385-405.

Teigeiro, L. R.; Solis, J.S. 2007. Coefficient stability and structural change in the Spanish economy, Economic Change and Restructuring (40): 387-409.

Thomas, S.; Ryan, C.; Wong, J.W.; Chan, A. P. C.; Chiang, Y. H.; Lam, P. T. I.; Kumaraswamy, M. 2009. Coping with structural change in construction: experiences gained from advanced economies, Construction Management and Economics 27: 165-180.

United Nations Industrial Development Organization. 2011. Industrial energy efficiency for sustainable wealth creation. Industrial Development Report 2011.261 p.

Woodall, C.W.; Ince, P.J.; Skog, K.E.; Aguilar, F.X.; Keegan, C.E.; Sorenson, C.B.; Hodges, D.G.; Smith, W.B. 2012. An overview of the forest products sector downturn in the United States, Forest Product Journal 61(8): 595-603. 


\section{Appendix}

\section{Classification of the countries by income group}

\begin{tabular}{|c|c|c|c|c|}
\hline \multirow{2}{*}{$\begin{array}{l}\text { Developed } \\
\text { economies }\end{array}$} & \multicolumn{4}{|c|}{ Developing economies } \\
\hline & High income & Upper middle income & Lower middle income & Low income \\
\hline Australia & Bahrain & Algeria & Albania & Bangladesh \\
\hline Austria & Brunei Darussalam & Argentina & Angola & Benin \\
\hline Belgium & Croatia & $\begin{array}{l}\text { Belarus } \\
\text { Bosnia and }\end{array}$ & Armenia & Cambodia \\
\hline Canada & Cyprus & Herzegovina & $\begin{array}{l}\text { Azerbaijan } \\
\text { Bolivia, Plurinational }\end{array}$ & Congo, Dem. Rep. \\
\hline Czech Republic & Estonia & Botswana & State & Ethiopia \\
\hline Denmark & Hong Kong SAR China & Brazil & Cameroon & Eritrea \\
\hline Finland & Israel & Bulgaria & China & Ghana \\
\hline France & Kuwait & Chile & Congo & Haiti \\
\hline Germany & Malta & Colombia & Côte d'Ivoire & Kenya \\
\hline Greece & Oman & Costa Rica & Ecuador & Korea, Dem. People's Rep. \\
\hline Hungary & Qatar & Cuba & Egypt & Kyrgyzstan \\
\hline Iceland & Saudi Arabia & Dominican Rep. & El Salvador & Mozambique \\
\hline Ireland & Singapore & Gabon & Georgia & Myanmar \\
\hline Italy & $\begin{array}{l}\text { Slovenia } \\
\text { Taiwan Province of }\end{array}$ & Jamaica & Guatemala & Nepal \\
\hline Japan & China & Kazakhstan & Honduras & Senegal \\
\hline Korea, Rep. & Trinidad and Tobago & Lebanon & India & Tajikistan \\
\hline Luxembourg & United Arab Emirates & $\begin{array}{l}\text { Latvia } \\
\text { Libyan Arab }\end{array}$ & Indonesia & Tanzania, United Rep. \\
\hline Netherlands & & Jamahiriya & Iran, Islamic Rep. & Togo \\
\hline New Zealand & & Lithuania & Jordan & Uzbekistan \\
\hline Norway & & Macedonia, Former & Moldova & Viet Nam \\
\hline Portugal & & Yugoslav Rep. & Mongolia & Yemen \\
\hline Slovakia & & Malaysia & Morocco & Zambia \\
\hline Spain & & Mexico & Nicaragua & Zimbabwe \\
\hline Sweden & & Namibia & Nigeria & \\
\hline Switzerland & & Panama & Pakistan & \\
\hline United Kingdom & & Peru & Paraguay & \\
\hline United States & & Poland & Philippines & \\
\hline & & Romania & Sri Lanka & \\
\hline & & Russian Federation & Sudan & \\
\hline & & Serbia & Syrian Arab Rep. & \\
\hline & & South Africa & Thailand & \\
\hline & & Turkey & Tunisia & \\
\hline & & Uruguay & Turkmenistan & \\
\hline & & Venezuela & Ukraine & \\
\hline
\end{tabular}

Source: UNIDO (Industrial development report 2011) 